\title{
European Legislative Initiative for Very Large Communication Platforms
}

Jan Christopher Kalbhenn

Abstract: In December 2020, the European Commission published its drafts for a Digital Services Act and a Digital Markets Act. With this legislative project the Commission introduces new regulations for the content moderation and market behaviours of very large online platforms, especially social networks. In addition to fixed requirements for all online platforms, due diligence requirements are also introduced for very large online platforms. This is intended to protect a wide range of legal interests, including public health, civil society discourse, or effects in connection with elections. This would also allow the Commission to push for further targeted measures in relation to hate speech, as well as disinformation under certain conditions and in the event of non-compliance with the rules of the Digital Services Act. It is possible that specifications on the interface design and algorithm architecture of the platform could be tailored to individual platforms.

Keywords: online platform; Digital Services Act; Digital Markets Act; content moderation; due diligence; media law; disinformation; hate speech; risk assessment and risk mitigation; design specifications; recommender system; social media; advertisement.

\section{Chapter 1. Europe-wide regulation of digital platforms}

The effects of the internet and platform economy were recently analysed by the media scientist and philosopher Joseph Vogl. His verdict is trenchant and drastic. From the rule of the financial markets to the new network giants to the dynamized opinion industry, lies a trail of destruction. Democracy, freedom and social responsibility are being damaged. In the digital age, new forms of entrepreneurial power have emerged that overwrite democracy with their own evaluation logic. Tech companies would intervene ever more massively in the decision-making of governments, so- 
cieties and economies across national borders. ${ }^{1}$ The European Commission has also taken a look at the impact of the platform economy and the dominance of individual tech companies. Following the 2018 General Data Protection Regulation and the 2019 Copyright Directive, the Commission presented another legislative package for the internet in December 2020. ${ }^{2}$ The draft Digital Markets Act contains competition rules for gatekeepers. The draft Digital Services Act contains media law requirements for platforms to protect fundamental rights on online platforms. Both sets of rules set particularly far-reaching specifications for especially large platforms. The Commission is thus also addressing the problem of hate speech and disinformation, not least in response to national go-it-alone measures such as the German Network Enforcement Act and the State Media Treaty. ${ }^{3}$ Decision-making practice on abuse of dominant market positions by dominant platforms is also given legal form.

This article shows how the Commission intends to ensure protection of fundamental rights on large platforms and guarantee fair competition by holding very large platforms in particular to account and in doing so also imposing requirements on the architecture of the algorithms and design of platform interfaces.

\section{Chapter 2. Digital Services Act and Digital Markets Act}

\section{Chapter 2.a. Background}

In December 2020, the European Commission presented the European Action Plan for Democracy. ${ }^{4}$ This is a catalogue of measures to be implemented over the entire term of the current Commission. The Commission's overarching goal is to empower citizens and build more resilient

1 Joseph Vogl, Kapital und Ressentiment, 2021.

2 List of EU Regulatory Instruments on Digital Platforms see Annex to this Article.

3 Another law with references to media law platform regulation is the Commission's proposed AI Act, See Kalbhenn, Jan „Designvorgaben für Chatbots, Deepfakes und Emotionserkennungssysteme: Der Vorschlag der Europäischen Kommission zu einer KI-VO als Erweiterung der medienrechtlichen Plattformregulierung“, ZUM Zeitschrift für Urheber- und Medienrecht, No. 8/9 (2021).

4 European Commission, Communication from the commission to the European Parliament, the Council, the European Economic and Social Committee and the Committee of the Regions, on the European democracy action plan, Brussels, 3.12.2020. 
democracies across the EU. Specifically, free and fair elections are to be promoted, media freedom expanded, and disinformation combated. In it, the European Commission states that the 'digital revolution' has changed democracy. In the digital realm, it is fundamentally challenging to enforce the law, and there are concerns about the transparency and accountability of online platforms. As concrete measures, the Commission announced uniform legislation on these issues across Europe. Many of the issues raised have so far been addressed through non-binding voluntary commitments and codes of conduct. These measures, for example in the area of hate speech and disinformation, were generally viewed positively. However, not least because of national solo efforts in regulation of online platforms such as social networks, the Commission has also recognized the need to achieve EU-wide harmonization of application of the law. For example, Germany, France and Austria already have or are planning initial laws to combat hate speech on social networks. ${ }^{5}$ Germany has also already enacted the first media law regulations for communication platforms. ${ }^{6}$

A similar picture emerges in competition law. In recent years, the European Commission has increasingly conducted proceedings against the major platform companies and has regularly found abuse of market power. ${ }^{7}$ National antitrust authorities in the Member States have also made high-profile decisions in this area, such as the German Federal Cartel Office prohibiting Facebook from combining user data from its Facebook, WhatsApp and Instagram services. ${ }^{8}$

With both draft regulations - the Digital Markets Act and the Digital Services Act - the Commission has initiated the legislative process. The EU

5 Maximilian-Hemmert-Halswick "Lessons learned from the first years with the NetzDG" (chapter in this book); these laws are also criticized for violating the principle of origin laid down in Art. 3 E-Commerce Directive. According to this, the place of establishment is decisive for an online company in legal terms and the respective member state is responsible for enforcing the law. The EU was forced to react to these developments and national advances with the Digital Services Act and to bring order to the legal system.

6 Bernd Holznagel and Jan Kalbhenn "Media law regulation of social networks" (chapter in this book).

7 Andreas Grünwald, "Big Tech-Regulierung zwischen GWB-Novelle und Digital Markets Act”, MMR - Zeitschrift für IT-Recht und Recht der Digitalisierung, No. 12 (2020).

8 German Federal Cartel Authority, Case Summary, Facebook, Exploitative business terms pursuant to Section 19(1) GWB for inadequate data processing, 15 February 2019, https:/www.bundeskartellamt.de/SharedDocs/Entscheidung/EN/Fallbericht e/Missbrauchsaufsicht/2019/B6-22-16.pdf?_blob=publicationFile\&v=4. 
has decided to propose the legislative acts in the form of regulations. These laws would apply directly in all Member States of the European Union after a transition period, as also applied to the General Data Protection Regulation (GDPR). As a result, the Digital Services Act and the Digital Markets Act would supersede the previously applicable law in their areas of application in favour of uniform regulation. However, there is still a long way to go before the final text of the regulation is adopted.

\section{Chapter 2.b. Regulatory targets}

The Digital Service Act (DSA) has two main purposes. On the one hand, creation of uniform rules for all Member States is intended to promote the - digital - single market. ${ }^{9}$ Another objective is to ensure protection of EU citizens' fundamental rights on the internet. ${ }^{10}$ This primarily involves protection of freedom of expression, protection of the personal rights of those affected by hate speech, and protection of freedom of information.

The Digital Markets Act (DMA) is also intended to impose harmonised rules on central platform services throughout Europe by way of a regulation, thus ensuring competition and fair digital markets throughout the Union in which gatekeepers operate. ${ }^{11}$

\section{Chapter 2.c. Focus on very large platforms}

To achieve these goals, the Digital Services Act creates a comprehensive set of regulations for the online economy and addresses intermediaries. Media law regulations are also created or supplemented in the process. The draft follows the principle of graduated responsibility. The decisive factor is initially how "close" the intermediary is to the content and to which group the content is made accessible. Only rudimentary obligations apply to companies that are solely responsible for infrastructure or temporary intermediate storage, such as internet access providers. Extended obligations apply to hosting services such as cloud and web hosting providers. The Digital Services Act imposes strict requirements on online platforms. These are defined very broadly as hosting service providers that allow

9 Art. 1 sec. 1 DSA.

10 Art. 1 sec. 1 DSA.

11 Art. 1 sec. 1 DMA. 
users to store and share information with the public. ${ }^{12}$ The size of online platforms also plays a role. Small platforms are excluded from the scope of specific obligations and are spared in favour of innovativeness. ${ }^{13}$ Very large online platforms, on the other hand, are subject to significant obligations. These are online platforms that have an average of 45 million active users in the EU. ${ }^{14}$ Very large online platforms include Facebook, Twitter, YouTube, Twitch, Instagram, and TikTok.

The Digital Markets Act imposes further binding obligations on these digital companies. It focuses on 'central platform services'. These are a series of services that are listed exhaustively. They include online brokerage services such as AirBnB, online search engines such as Google Search, social networks such as Instagram and TikTok, video sharing platform services such as YouTube, messenger services such as WhatsApp, operating systems, cloud computing services, and advertising services, including advertising networks and advertising exchanges. The obligations of the Digital Markets Act only apply to operators of central platforms if they are designated as gatekeepers pursuant to Art. 3 DMA. The prerequisite for this designation is that the platform service has a significant impact on the internal market, and operates a central platform service that serves commercial users as an important gateway to end users. With regard to its activities, it must hold a consolidated and permanent position. However, it is also sufficient if it is foreseeable that it will attain such a position in the near future. ${ }^{15}$ Art. 3 DMA regulates the procedure to ensure that the Commission becomes aware of the fact that a company's thresholds have been reached. Gatekeeper status will be reviewed on a regular basis, and the designation may be changed or revoked. ${ }^{16}$ Thus, the Digital Markets Act basically covers such platforms that are addressed in the Digital Services Act as very large platforms - including TikTok, Instagram, Twitter, and so on.

\section{Chapter 3. The new ABC of European platform regulation}

The Digital Services Act sets out to make the internet a secure, predictable and trustworthy environment in the age of the platform economy and social networks. The fundamental rights enshrined in the European Char-

12 Art. 2 lit. h DSA.

13 Art. 16 DSA.

14 Art. 25 DSA.

15 Art. 3 sec. 1 DMA.

16 Art. 4 DSA. 
ter of Fundamental Rights are to be effectively protected. The definition catalogue in Article 2 of the Digital Services Act already sets out the field for this. The dangers to certain legal interests posed by platforms come primarily from the content disseminated there and the way content is presented and weighted. ${ }^{17}$ It is therefore not surprising that the definition catalogue contains many key terms that relate to certain categories of content (advertising, illegal content) or their mediation (content moderation, recommendation system). In some cases, these terms are now being defined for the first time.

\section{Chapter 3.a. Content moderation}

The term 'content moderation' is central to the goals and objectives of the Digital Services Act. This is understood by the draft to mean the activities of providers of intermediary services to identify, determine and combat illegal content or information provided by users that is incompatible with the provider's general terms and conditions. This includes measures related to the availability, visibility and accessibility of illegal content or information. ${ }^{18}$ Downgrading, blocking access or removal are given as examples. Also included are measures that restrict the ability of users to provide information. This also includes closure or temporary suspension of a user account for content moderation. This definition is very broad. Thus, the Digital Services Act affects all means available to platforms to manage content.

\section{Chapter 3.b. Illegal content}

Illegal content is a special category of content to which the Digital Services Act attaches certain legal consequences. The Digital Services Act defines this as all information that does not comply with EU law or the law of a Member State. ${ }^{19}$ This can also include content that violates the law by referring to an activity. It also covers sale of products or provision of services. This very broad definition and the equally broad definition

17 Sinan Aral, The Hype Machine, London, 202; Maik Fielitz and Holger Marcks, Digitaler Faschismus, Berlin 2020.

18 Art. 2 lit. p DSA.

19 Art. 2 lit. g DSA. 
of online platforms result in a wide scope of application of the Digital Services Act. Even trading platforms such as Amazon and eBay are subject to the regulations on content moderation of illegal content.

\section{Chapter 3.c. Advertising}

Advertising is central to the business model of many platforms. ${ }^{20}$ Even the Amazon trading platform is increasingly generating revenue from advertising. Advertising is a special content category to which both the Digital Service Act and the Digital Markets Act attach certain legal obligations. For both sets of regulations, the Digital Services Act defines what is meant by advertising. According to this definition, it is information intended to disseminate the message of a legal or natural person that is displayed by an online platform for publicity in return for payment. ${ }^{21}$ Advertising for non-commercial purposes is also included. In terms of legal consequences, the Digital Services Act differentiates between general advertising and advertising 'delivered' by micro-targeting.

\section{Chapter 3.d. Recommendation systems}

Not least to deliver money-making content, advertising, to the user, recommendation systems are essential components of the architecture of online platforms. Without algorithmic moderation, organisation of the mass of content would not be possible. At the same time, the personalization they enable is a central component of (advertising) business models. The Digital Services Act defines this as a fully or partially automated system used by an online platform to suggest specific information to users. ${ }^{22}$ This can be triggered either by a search or by other means. This must determine the relative order or prominence of the information displayed.

20 Tim Hwang, Subprime Attention Crisis, New York, 2020. Shoshana Zuboff, The Age of Surveillance Capitalism: The Fight for a Human Future at the New Frontier of Power, New York: PublicAffairs, 2019.

21 Art. 2 lit. n DSA.

22 Art. 2 lit. o DSA. 
Chapter 3.e. General terms and conditions

The legal relationship between online platforms and their users is initially governed by civil law. This is usually done by means of general terms and conditions. What is meant by this is defined uniformly for all Member States by the Digital Services Act. They are any terms, conditions or specifications, regardless of their name or form, that govern the contractual relationship between the provider of intermediary services and users. ${ }^{23}$ Behind this are also the community standards that have reached a high level of detail on communication platforms such as Facebook, for example, and according to which content is deleted or blocked millions of times. The Digital Services Act does not shy away from intervening in the contractual relationship between platforms and users and prescribing minimum requirements.

Chapter 4. Rigid requirements for content moderation in the Digital Services Act.

Overview of new obligations ${ }^{24}$

\begin{tabular}{|c|c|c|c|c|}
\hline & $\begin{array}{l}\text { Interme- } \\
\text { diary } \\
\text { services } \\
\text { (cumula- } \\
\text { tive obli- } \\
\text { gations) }\end{array}$ & $\begin{array}{c}\text { Hosting } \\
\text { services } \\
\text { (cumu- } \\
\text { lative } \\
\text { obliga- } \\
\text { tions) }\end{array}$ & $\begin{array}{l}\text { Online } \\
\text { plat- } \\
\text { forms } \\
\text { (cumu- } \\
\text { lative } \\
\text { obliga- } \\
\text { tions) }\end{array}$ & $\begin{array}{l}\text { Very } \\
\text { large } \\
\text { plat- } \\
\text { forms } \\
\text { (cumu- } \\
\text { lative } \\
\text { obliga- } \\
\text { tions) }\end{array}$ \\
\hline Transparency reporting & - & - & - & $\square$ \\
\hline $\begin{array}{l}\text { Requirements on terms of service } \\
\text { due on account of fundamental } \\
\text { rights }\end{array}$ & - & - & - & घ \\
\hline $\begin{array}{l}\text { Cooperation with national au- } \\
\text { thorities following orders }\end{array}$ & च & च & च & च \\
\hline
\end{tabular}

23 Art. 2 lit. q DSA. 


\begin{tabular}{|c|c|c|c|c|}
\hline & $\begin{array}{l}\text { Interme- } \\
\text { diary } \\
\text { services } \\
\text { (cumula- } \\
\text { tive obli- } \\
\text { gations) }\end{array}$ & $\begin{array}{c}\text { Hosting } \\
\text { services } \\
\text { (cumu- } \\
\text { lative } \\
\text { obliga- } \\
\text { tions) }\end{array}$ & $\begin{array}{l}\text { Online } \\
\text { plat- } \\
\text { forms } \\
\text { (cumu- } \\
\text { lative } \\
\text { obliga- } \\
\text { tions) }\end{array}$ & $\begin{array}{c}\text { Very } \\
\text { large } \\
\text { plat- } \\
\text { forms } \\
\text { (cumu- } \\
\text { lative } \\
\text { obliga- } \\
\text { tions) }\end{array}$ \\
\hline $\begin{array}{l}\text { Points of contact and, where nec- } \\
\text { essary, legal representative }\end{array}$ & घ & घ & घ & घ \\
\hline $\begin{array}{l}\text { Notice and action and obligation } \\
\text { to provide information to users }\end{array}$ & & - & घ & घ \\
\hline $\begin{array}{l}\text { Complaint and redress mecha- } \\
\text { nism and out of court dispute set- } \\
\text { tlement }\end{array}$ & & & घ & - \\
\hline Trusted flaggers & & & $\mathbf{\square}$ & $\mathbf{\square}$ \\
\hline $\begin{array}{l}\text { Measures against abusive notices } \\
\text { and counter-notices }\end{array}$ & & & - & घ \\
\hline $\begin{array}{l}\text { Vetting credentials of third- party } \\
\text { suppliers ("KYBC") }\end{array}$ & & & $\boldsymbol{\square}$ & घ \\
\hline $\begin{array}{l}\text { User-facing transparency of on- } \\
\text { line advertising }\end{array}$ & & & $\mathbf{\square}$ & $\mathbf{\square}$ \\
\hline Reporting criminal offences & & & 口 & $\mathbf{\square}$ \\
\hline $\begin{array}{l}\text { Risk management obligations } \\
\text { and compliance officer }\end{array}$ & & & & घ \\
\hline $\begin{array}{l}\text { External risk auditing and public } \\
\text { accountability }\end{array}$ & & & & $\mathbf{\square}$ \\
\hline $\begin{array}{l}\text { Transparency of recommender } \\
\text { systems and user choice for access } \\
\text { to information }\end{array}$ & & & & $\boldsymbol{\square}$ \\
\hline $\begin{array}{l}\text { Data sharing with authorities and } \\
\text { researchers }\end{array}$ & & & & $\mathbf{\square}$ \\
\hline Codes of conduct & & & & $\boldsymbol{\square}$ \\
\hline
\end{tabular}

24 https://ec.europa.eu/info/strategy/priorities-2019-2024/europe-fit-digital-age/digital -services-act-ensuring-safe-and-accountable-online-environment_en. 


\begin{tabular}{|c|c|c|c|c|}
\hline & $\begin{array}{l}\text { Interme- } \\
\text { diary } \\
\text { services } \\
\text { (cumula- } \\
\text { tive obli- } \\
\text { gations) }\end{array}$ & $\begin{array}{c}\text { Hosting } \\
\text { services } \\
\text { (cumu- } \\
\text { lative } \\
\text { obliga- } \\
\text { tions) }\end{array}$ & $\begin{array}{l}\text { Online } \\
\text { plat- } \\
\text { forms } \\
\text { (cumu- } \\
\text { lative } \\
\text { obliga- } \\
\text { tions) }\end{array}$ & $\begin{array}{c}\text { Very } \\
\text { large } \\
\text { plat- } \\
\text { forms } \\
\text { (cumu- } \\
\text { lative } \\
\text { obliga- } \\
\text { tions) }\end{array}$ \\
\hline Crisis response cooperation & & & & [ \\
\hline
\end{tabular}

Chapter 4.a. Transparency as a basic rule of content moderation

With the central provision in Article 12 Digital Services Act, the legislator intervenes in the contractual relationship between platform and user. The Digital Services Act supplements contract law in the area of platform general terms and conditions (GTCs) and community standards. The content of GTCs is not specified, for example by model GTCs. However, certain information must be provided. For example, information must be provided on any restrictions on the information provided by users that they impose in connection with use of their service. Disclosures must include information about any policies, procedures, measures, and tools used to moderate content, including algorithmic decision making and human review. This is appropriate since content moderation is now heavily processed algorithmically. ${ }^{25}$ Information must also be understandable and made publicly available in an easily accessible form. If these rules are part of the contract, users can also take legal action to enforce them.

Online platforms must also clearly state in their terms and conditions how they handle account suspensions. ${ }^{26}$ The Digital Services Act stipulates those accounts of users who frequently provide obviously illegal content must be blocked. The Digital Services Act thus defines a minimum standard of protection. However, platform providers can also ${ }^{27}$ set a higher standard of protection as long as fundamental rights are respected. This is because, according to Art. 12(2) Digital Services Act, when applying and enforcing the restrictions designated in their community standards, they

25 Kate Klonick, "The Facebook Oversight Board: Creating an Independent Institution to Adjudicate Online Free Expression”, The Yale Law Journal, 2021.

26 Art. 20 sec. 4 DSA.

27 Art. 20 sec. 1 DSA. 
must do so carefully, objectively and proportionately, taking into account the rights of all stakeholders, as well as the applicable fundamental rights of users. This makes the fundamental rights of users the benchmark for content moderation on online platforms.

In their general terms and conditions, online platforms must also present the key parameters of recommendation systems.

\section{Chapter 4.b. Account suspensions in case of abusive behaviour}

For the first time, a regulation uniform for all online platforms is envisaged, which would set the conditions under which accounts on communication platforms are to be blocked. The standard formulates a minimum standard that does not prevent online platforms from providing stricter regulations in their community standards. ${ }^{28}$ Online platforms are to suspend user accounts at least temporarily in the event of abusive behaviour - if a user frequently posts obviously illegal content. In this context, that is the case if a layperson recognizes it as evidently unlawful without closer examination. ${ }^{29}$

\section{Chapter 4.c. Recommendation systems}

With the design of user interfaces, online platforms can strongly influence users' decisions. Selection behaviour by users depends on how highlighted or hidden, understandable or incomprehensible are certain functions offered. ${ }^{30}$ If legislators are concerned that a function is not hidden from users by platform services, they can use design specifications to ensure that a particular option is present in the interface design. The Commission has opted for such a requirement in the area of algorithmic recommendation systems for content moderation, to which the Commission rightly attaches central importance in dissemination of content. ${ }^{31}$ In the recitals, the Commission refers to the considerable potential of systems to spread certain messages virally. The Digital Services Act initially aims to counter these

28 Recital 47 DSA.

29 Recital 47 DSA.

30 Cliff Kuang and Robert Fabricant, User Friendly, London 2019.

31 Natali Helberger, "On the Democratic Role of News Recommenders", 2019, Digital Journalism, 993-1012. 
risks through transparency. Very large online platforms must therefore present the most important parameters of recommendation systems in an accessible and easily understandable way in their general terms and conditions. All options with which the most important parameters can be changed or influenced are to be pointed out. User autonomy is to be strengthened by providing at least one profiling-free (as defined by the GDPR) option. ${ }^{32}$ The Digital Services Act makes a design specification in the event that several such options are provided. In that case, the design of the user interface must provide an 'easily accessible function' for the user to select the recommendation system.

\section{Chapter 4.d. Complaint management for illegal content}

The Digital Services Act provides a differentiated regime for dealing with illegal content. The principle of 'notice-and-takedown' continues to apply. The new requirements for complaint management aim to make it as easy as possible for platform users or civil society organizations to give notice. By imposing organisational requirements on network operators, they are to be given opportunities to have illegal content removed from online platforms. The Digital Services Act does not contain details on takedown contrary to the German Netzwerkdurchsetzungesgesetz (NetzDG) that sets time limits for deletion or blocking of content. Again, stricter requirements are placed on online platforms and very large online platforms than on hosting services.

\section{a) Upward compatible ground rules for all hosting services}

The basic rules for hosting providers are upwardly compatible and apply to all online platforms. All hosting services must set up an easy-to-use complaints system..$^{33}$ This is intended to allow users to submit complaints that enable providers to make a qualified decision on the illegality of the content. Consistently, certain requirements must be met. To be included: Reasons for the illegality, exact location (URL), name and e-mail address of the complainant included. In addition, the complainant should receive an acknowledgement of receipt and is entitled to a speedy decision. If

32 Art. 29 sec. 1 DSA.

33 Art. 14 sec. 1 DSA. 
the decision is based on artificial intelligence or automation, this must be made transparent.

If content is removed or blocked, the person concerned should be fully informed of the reasons. ${ }^{34}$ The legal standard violated must be stated, as well as the circumstances on which the decision is based. Reasons must also be given for violations of community standards.

\section{b) Special regulations for online platforms}

The rights of users are to be protected by differentiated procedural requirements. Online platforms should set up an internal complaints management system enabling checks on whether content has been deleted or blocked. Temporary suspension from platform use or deletion of the user account should also be handled via this. ${ }^{35}$ The review must be free of charge and easily accessible. Complaints must be made available for violations of legal regulations but also of community standards. The decision on the complaint should also be made expeditiously and the complainant must be informed of the decision. The decision in the complaint procedure must not be based exclusively on an automated procedure. ${ }^{36}$ In the initial complaint procedure, on the other hand, a fully automated decision may be issued. ${ }^{37} \mathrm{~A}$ human being must be involved in renewed control ("buman in the loop"). Providers must draw the attention of the data subject to the possible alternative procedure in the decision.

\section{c) Low-threshold out-of-court alternative procedure}

Users whose content has been deleted or blocked should be able to challenge the decisions from the online platform complaints procedure in an out-of-court procedure. ${ }^{38}$ For this purpose, out-of-court dispute resolution bodies are to be established, which in turn require recognition and

34 Art. 15 DSA.

35 For details on the NetzDG amendment 2021 see Hemmert-Halswick "Lessons learned from the first years with the NetzDG" (Chapter in this book).

36 Art. 17 sec. 5 DSA.

37 Kalbhenn and Hemmert-Halswick, „EU-weite Vorgaben für die Content-Moderation in sozialen Netzwerken“, ZUM - Zeitschrift für Urheber- und Medienrecht, No. 3 (2021).

38 Art. 18 DSA. 
must first meet certain conditions - prove that they are impartial and independent of online platforms and users, have the necessary expertise, maintain clear and fair rules of procedure, and are easily accessible by electronic communication (18 (2) DSA). Member States are allowed to set up arbitration bodies themselves. ${ }^{39}$ This offers civil society organizations an opportunity to help shape the legal framework for content moderation. There is also the option of seeking legal protection in court. ${ }^{40}$

\section{d) Trusted flaggers}

Another gateway for civil society to help shape content moderation is hidden in the regulation on trusted flags. This status can be granted to public bodies or non-governmental organizations and 'semi-public' bodies, for example organizations that report illegal, racist and xenophobic statements on the internet. ${ }^{41}$ In content moderation, some platforms already rely on trusted flaggers. YouTube traditionally uses trusted partners in the area of copyright to feed the Content ID system. ${ }^{42}$ In the area of other content control, YouTube also grants this status to individual organisations and confers on their reports increased trustworthiness. Such reports are processed more quickly. In the future, the Digital Services Act will shape this practice, which has so far been purely a matter of private law, into law. ${ }^{43}$ Online platforms will then be obligated to ensure technically and organisationally that reports from trusted flaggers are processed with priority and without delay. In that way, the speed of measures against illegal content can be increased.

Trusted Flaggers may only be institutions but not individuals. They must prove that they have special expertise and competence in combating illegal content. It is also a prerequisite that they represent collective interests. They must work carefully and objectively.

The rule guarantees a legally secure status for Trusted Flagger from erratic platform decisions by providing legal certainty. YouTube currently reserves the right to change the eligibility requirements for the Trusted Flag-

39 Art. 18 sec. 4 DSA.

40 In Germany, there is already much case law on content moderation, see Holznagel and Kalbhenn "Media law regulation of social networks" (chapter in this book).

41 Recital 46 DSA.

42 Robert Gorwa et al., "Algorithmic content moderation: Technical and political challenges in the automation of platform governance”, Big Data \& Society, 2020.

43 Art. 19 DSA. 
ger programme or suspend the programme at its discretion. This would be unlawful under the Digital Services Act. The complete opposite of a Trusted Flagger is regulated in Art. 20 (2) DSA, namely users who frequently submit notices or complaints that are manifestly unfounded. In the future, online platforms are to block these users from reporting further content.

\section{Chapter 4.e. Serious crimes}

Online platforms are to be obliged to inform the danger prevention or law enforcement authorities in the event of a suspected serious crime. ${ }^{44}$ This is about protecting the life or safety of persons. The recitals make it clear that this requirement does not legitimize profiling or similar planned observations. ${ }^{45}$

\section{Chapter 4.f. Advertising}

One content category that is particularly valuable for platforms is advertising. The Digital Services Act distinguishes between advertising that is displayed equally to all users (standard advertising) and advertising that is displayed individually to users via micro-targeting. ${ }^{46}$ Online platforms must make standard advertising clearly recognisable as advertising and allow the advertiser to be identified. ${ }^{47}$ Advertising using micro-targeting should contain meaningful information about the key addressing parameters. The logic used should be explained in a meaningful way. ${ }^{48}$

Very large platforms are subject to even more stringent transparency requirements. They pose an increased risk due to their reach. They also have more data at their disposal to perfect behavioural analysis for targeted advertising, with the associated increased risks. Very large online platforms must now store the content of the ad, the advertiser, the period of the ad, the specification of recipient groups and important parameters for targeting, and the total number of recipients reached one year after the

44 Art. 21 DSA.

45 Recital 48 DSA.

46 On the human rights impact of microtargeting ads see Judit Bayer, "Double harm to voters: data-driven micro-targeting and democratic public discourse", Internet Policy Review, 9(1) 2020.

47 Art. 24 DSA.

48 Recital 52 DSA. 
last insertion in a publicly accessible database. ${ }^{49}$ Industry standards are intended to make advertising databases interoperable. ${ }^{50}$ This should make it easier to analyse the risks associated with the spread of advertising. The Recitals of the Digital Services Act refer to unlawful advertising or manipulative techniques and disinformation that have a negative impact on public health, public safety, civil discourse, political participation and equality. ${ }^{51}$

For political advertising, the Commission has announced a legislative act in the Action Plan for Democracy.

\section{Chapter 4.g. Official announcements}

Very large online platforms also play a central role in informing citizens in crisis situations. Situations where public safety or public health are at risk - such as the Corona pandemic or attacks - misinformation spreads particularly quickly via online platforms and can lead to further damage. For such situations, the Commission is to develop crisis protocols for content moderation with Member State authorities. ${ }^{52}$ For example, it may be regulated that information from national authorities is displayed prominently. Some platforms have implemented such measures voluntarily so far. Facebook prioritized displaying information from the World Health Organization during the Corona pandemic and enabled a missing-personssearch-feature during the attacks on the Bataclan theatre in Paris. This far-reaching regulation appears appropriate in view of the high reach of the platforms and their partial monopoly position. In European telecommunications law, it is still possible to set up public warning systems via messenger services.

\section{Chapter 4.h. Interim summary}

In the systematics of the Digital Services Act, the completed catalogue of rigid rules for content moderation represents a minimum standard

49 Art. 30 DSA. This rule builds on the Code of Conduct and has already been implemented by some platforms - not to the full satisfaction of critics - on a voluntary basis.

50 Art. 34 sec. 1 lit. b DSA.

51 Recital 63 DSA.

52 Art. 37 DSA. 
applicable to all online platforms, regardless of the business model of the platform service, the content distributed there, or the target group. Gradations are only made with regard to the size of online platforms. The rules apply in the same way to platforms as diverse as Airbnb, TikTok, Amazon and Parler. This is not surprising, given that minimum standards for protection of fundamental rights should be ensured by procedural rules on all platforms. It is striking that many of the rules are already in place in German media law, in the shape of the Network Enforcement Act of 2017 and the State Media Treaty. ${ }^{53}$

In order to counter highly complex dangers such as disinformation with targeted regulation, other factors must be taken into account. The business model pursued by the platform service, the media competence of the user community and, last but not least, the precise (algorithm) architecture and the interface design of platforms are all relevant. Architecture and design are significantly tailored to the business model. Only when these and other factors are included a sustainable regulation and a threat mitigation is possible. To contain systemic risks, the Digital Service Act therefore relies on flexible specifications for very large platforms and creates extensive due diligence obligations.

Chapter 5. Flexible specifications for systemic risks of very large platforms

\section{Chapter 5.a. Risk assessment}

For very large online platforms such as Facebook, Instagram, TikTok, YouTube, iTunes and Spotify, the Digital Services Act presents a flexible instrument aimed at protecting a wide range of legal interests and taking into account the specifics and business models of the services. Additional obligations are imposed for managing systemic risks. Central to this is a mechanism for assessing and minimizing risks. According to Art. 26 DSA, it is to become mandatory for very large online platforms to identify, analyse and assess all material systemic risks arising from the operation and use of their services once a year. Mandatorily, the risk analysis has to include the following three points:

53 Kalbhenn and Hemmert-Halswick, "EU-weite Vorgaben für die Content-Moderation in sozialen Netzwerken". 
- dissemination of illegal content,

- the negative impact on the exercise of fundamental rights (in particular, private and family life, freedom of expression and information, prohibition of discrimination, and rights of the child); and

- intentional manipulation of their service with a negative impact on protection of public health, minors, civil discourse, or impact related to elections and public safety.

Risks in the latter area can arise, for example, from the use of bots or (partially) automated communication. ${ }^{54}$ Risk assessment must primarily consider content moderation systems, recommendation systems, and systems for selecting and displaying advertising.

\section{Chapter 5.b. Minimisation of risks}

Very large online platforms will be required to minimize the risks thus identified. ${ }^{55}$ To this end, they are to take appropriate, proportionate and effective risk mitigation measures tailored to the systemic risks identified. A wide range of possible adjustments is conceivable here. This also applies to the design and architecture of the platforms. The law provides a non-exhaustive catalogue of examples of risk mitigation measures. According to this, risk mitigation can be achieved primarily by adapting content moderation or recommendation systems, decision-making processes, the features or functioning of their services, or their general terms and conditions. Targeted measures to restrict the display of advertising are also mentioned, as well as strengthening internal processes with regard to identifying systemic risks.

\section{Chapter 5.c. Audit, data access law, reporting}

It is initially the responsibility of the platforms to analyse and minimise risks. Whether the providers of very large online platforms also comply with these due diligence obligations is the subject of an annual independent audit. Detailed regulations are specified for this purpose. If very large online platforms receive a non-positive audit report, they must give due

54 Recital 68 DSA.

55 Art. 27 DSA. 
consideration to all operational recommendations addressed to them and take the necessary measures to implement them. If they do not implement recommendations, they are required to give reasons and outline alternative measures. ${ }^{56}$

Researchers should be given a framework for compelling access to data from very large online platforms. ${ }^{57}$ Facebook, YouTube, and the like should provide data to researchers limited to identifying and understanding systematic risks. The Digital Services Coordinator and Commission may also require access to data. For example, to rule on the accuracy and functional specifics of algorithmic systems, or for content moderation, recommendation systems, or advertising systems.

Very large platforms must publish a comprehensive transparency report once a year on risk identification, risk-minimising measures, the audit report and the resulting adjustments. This obligation is in addition to the existing reporting obligation for all intermediaries under Art. 13 DSA. ${ }^{58}$

\section{Chapter 5.d. Design specifications and architecture specifications}

In large-scale socio-technical systems, the design (interface) and architecture (algorithms) also play a significant role. ${ }^{59}$ These are central elements for influencing user engagement in the sense of the business model and for suggesting or facilitating certain decisions for users. ${ }^{60}$ For this and other platform specifics, the Commission can provide guidance under certain conditions as part of its oversight. This is because the Commission has a broad set of tools at its disposal for supervision, investigation and enforcement. This means that the Commission can also intervene in the design and architecture of very large online platforms. For example, if an online platform fails to comply with the provisions of the Digital Services Act, the Commission can take interim measures, ${ }^{61}$ declare commitments by very large online platforms to be binding, ${ }^{62}$ and issue orders for non-com-

56 Art. 28 DSA.

57 Art. 31 sec. 2 DSA.

58 Art. 33 sec. 2 DSA.

59 Jeffrey Chan, "Ethics in large-scale socio-technical systems", in Laura Scherling and Andrew DeRosa (eds.): Ethics in Design and Communication, New York 2020.

60 Nir Eyal, Hooked, New York, 2019; Cliff Kuang and Robert Fabricant, User Friendly, New York, 2019.

61 Art. 55 DSA.

62 Art. 56 DSA. 
pliance. ${ }^{63}$ If systemic risks are not effectively minimized, the Commission may, in cases of urgency due to the risk of serious harm to users, issue interim orders based on a prima facie finding of non-compliance. Although, these are to be limited in time. They may be extended. As interim injunctions, highly specific risk mitigation requirements can be imposed on platforms. The Commission can thus intervene directly in the (interface) design and (algorithm) architecture of online platforms. If, for example, it turns out that a systemic risk emanates from a certain algorithmic programming and the platform operator cannot get this under control, the Commission can issue concrete architectural specifications in this regard. Then, for example, reprogramming the weighting of algorithms could be specified. If it turns out that functions integrated into the design of the platform - such as an endless scroll - are prone to risk, direct design specifications can be made.

\section{Chapter 5.e. Summary}

Management of systemic risks is initially left to platforms through the assessment process with subsequent risk minimisation process. It is up to them to assess the risks in the designated fields and to make proposals as to how they can be minimised. However, the Commission does not have to stand idly by, but can intervene at all stages of this process. In addition, the audit promises to provide insights into the complex world of systemic risks posed by very large online platforms.

If stringent design or architectural requirements are imposed via interim injunctions, such requirements sometimes deeply interfere with the platform business model. However, the legal interests in question are allimportant, so that interference with the fundamental economic rights of service providers can be justified. A complete ban on certain designs and architectures is also conceivable. It would not be surprising if technologies such as endless scrolling, auto-play, or other designs discussed under the term 'dark pattern' were prohibited for certain platforms and certain target groups that are particularly worthy of protection (such as children). 
Chapter 6. Market conduct rules for gatekeepers in the Digital Markets Act.

The market power of a few large technology groups is considerable. At the same time, platform markets have special features, such as lock-ins and network effects. ${ }^{64}$ These first had to be understood by the regulatory authorities. In recent years, the EU Commission as well as national antitrust authorities have conducted several competition law proceedings against companies such as Apple, Microsoft, Google and Facebook. These companies were accused of obstruction and exploitation strategies, and very high fines were not infrequently imposed. The findings of these proceedings are now found as prohibitions and commandments in respect of certain behaviours in the market. The Digital Markets Act relies on ex ante regulation for these practices. Further orders are then not necessary for effectiveness. At the heart of the Digital Markets Act are the "obligations" in Art. 5 DMA and "obligations that may be further specified" enumerated in Art. 6 DMA.

Chapter 6.a. Rigid commandments and prohibitions

Art. 5 DMA contains rigid requirements and prohibitions for gatekeepers. There is no need for further concretisation in individual cases by the EU Commission. Accordingly, for gatekeepers the following is prohibited:

- merge personal data of different own services or services of third parties without a compliant consent according to General Data Protection Regulation (lit a),

- prevent commercial users from reporting matters related to gatekeeper practices to a competent authority (lit d),

- to require the use of its own identification service (lit e),

- make granting access dependent on a subscription or registration with another service (litf).

Mandatory gatekeepers must

- enable commercial users to offer the same products or services to end users at different prices or conditions than through the gatekeeper's online intermediary services (lit b),

64 Philipp Staab, Digitaler Kapitalismus, Berlin 2019; Nick Srnicek, Platform Capitalism, London 2017. 
- enable commercial users to promote offers to end users acquired through the central platform service (lit c),

- and to conclude contracts with these end users via the gatekeeper's central platform services or by other means (lit c),

- and enable end users to access or use content, subscriptions, features or other elements by using a business user's software application through the gatekeeper's central platform services, if the end user has purchased such elements from the relevant business user without using the gatekeeper's central platform services (lit g).

- advertisers and publishers receive information about publication of a particular advertisement and for each of the gatekeeper's relevant advertising services (lit g).

\section{Chapter 6.b. Other commandments and prohibitions}

Article 6 DMA contains further requirements and prohibitions. The law states that these "may contain obligations of gatekeepers that are to be specified in more detail". However, this is not explained further in the Digital Markets Act. The following practices are prohibited for gatekeepers:

- to use non-publicly accessible data generated via the central platform service by commercial users in competition with such commercial users (lit a),

- give preference in ranking to services and products offered by the gatekeeper itself over similar services or products offered by third parties, and must carry out the ranking on the basis of fair and non-discriminatory conditions (lit d),

- refrain from technically limiting the possibilities to switch between different software applications and services (lit e),

In addition, a number of bids are set up. Gatekeepers must:

- enable end users to uninstall software applications preinstalled on its central platform service (lit b),

- enable the installation and effective use of third-party software applications and app stores that use or interoperate with gatekeeper operating systems (lit c), ${ }^{65}$

65 Gatekeeper may take reasonable steps to ensure that third party software applications or third party operated stores for software applications do not compromise the integrity of hardware or operating systems provided by the gatekeeper. 
- provide commercial users and ancillary service providers with access to and interoperability with operating systems, hardware or software functions for the provision of ancillary services (lit $f$ ),

- Provide advertisers and publishers, free of charge, with access to performance measurement and information they need to conduct their own independent review of advertising inventory (lit g),

- ensure effective portability of data generated by users and end-users and provide tools to facilitate data transfer and ensure permanent real-time access (lit h),

- provide commercial users, free of charge, with effective, high-quality and permanent real-time access to data provided or generated in connection with use of the relevant central platform services by such commercial users and end-users using the products or services of such commercial users (lit i),

- grant third parties operating online search engines access to ranking, search, click and display data relating to unpaid and paid search results at their request on fair, reasonable and non-discriminatory terms (lit j);

- apply fair and non-discriminatory general terms and conditions for commercial users' access to its app store (lit k).

\section{Chapter 6.c. Enforcement of market rules for gatekeepers}

Powers of investigation, enforcement and monitoring are regulated in detail. It is also possible for certain obligations to be suspended upon request or to be exempted from obligations for compelling reasons of public interest. Under Article 22 DMA, in urgent cases where there is a risk of serious and irreparable harm to commercial users or end users of gatekeepers, the Commission may order interim measures against a gatekeeper on the basis of an infringement of Article 5 DMA or Article 6 DMA. Fines are possible in the amount of up to $10 \%$ of annual turnover.

Both with the DMA and the DSA, the European Commission proposes to centralize the supervision of digital corporations' cross-border conduct in the Union in its own hands. ${ }^{66}$

66 Torsten Gerpott „Wer reguliert zukünftig Betreiber großer Online-Plattformen?“, Wirtschaft und Wettbewerb, No. 9 (2021). 


\section{Chapter 7. Conclusion}

Joseph Vogl recently recommended a series of measures as a solution to 'infodemias' on the net: "Increase friction, reduce speed, insert cooling periods, extend pauses, increase signal noise, disrupt cycles, interrupt automatisms, shut down." ${ }^{67}$ With the Digital Services Act and the Digital Markets Act and other regulations, ${ }^{68}$ the European Commission is putting forward comprehensive proposals to regulate the digital economy. ${ }^{69}$ In doing so, it is responding comprehensively to the threat to legal assets and fundamental rights posed by online platform business models. The focus is on very large platforms, for which an extensive catalogue of obligations is being drawn up. These must first implement a catalogue of rigid requirements for content moderation that applies regardless of the type of platform or business model. Airbnb, Uber, Facebook, and Amazon must then make the criteria of their content moderation transparent, maintain advertising databases and offer non-personalized recommendation systems. This also interferes with the business models. Users will also be protected by certain procedural rules, such as specific requirements, among them the obligation to provide reasons in the case of content deletion and the possibility to object. Platforms must protect their users from users who regularly disseminate illegal content by temporarily blocking such accounts. These basic rules also address the involvement of artificial intelligence in the process. For the most part, these requirements are formulated as minimum standards, which also allow platforms to apply stricter standards. However, any content moderation measures must respect the fundamental rights of users.

67 Julia Encke and Harald Staun "Die Nutzer spielen mit", Frankfurter Allgemeine Sonntagszeitung, March 14, 2021, https://www.faz.net/aktuell/feuilleton/debatten /plattformkapitalismus-joseph-vogl-ueber-kapital-und-ressentiment-17241098.htm 1?printPagedArticle=true\#pageIndex_ 2 .

68 List of EU Regulatory Instruments on Digital Platforms see Annex to this Article; for European Artificial Intelligence Act see Jan Kalbhenn „Designvorgaben für Chatbots, Deepfakes und Emotionserkennungssysteme: Der Vorschlag der Europäischen Kommission zu einer KI-VO als Erweiterung der medienrechtlichen Plattformregulierung“, ZUM - Zeitschrift für Urheber- und Medienrecht, No. 8/9 (2021); for other Digital European Regulation see Boris Paal and Lea Kumkar „Die digitale Zukunft Europas“, ZfDR - Zeitschrift für Digitalisierung und Recht, No 2 (2021).

69 Regulation under telecommunications law as services of general interest could go even further, see Christoph Busch, Regulierung Digitaler Plattformen als Infrastruktur der Daseinsvorsorge, 2021. 
The Digital Services Act takes into account that online platforms cannot be lumped together. It makes a difference whether information and opinions are disseminated or goods are offered for sale on a very large online platform. Advertising-driven offerings also regularly pose different risks than those in which the individual conclusion of a contract is settled with commissions. Systemic risks of this kind are a complex matter that must be assessed differently from platform to platform. Correctly, the Digital Services Act relies on due diligence to address these risks. ${ }^{70}$ In this regard, it is first in the hands of platforms to procure empiricism and identify risks. The right of initiative to mitigate risks also lies with the platforms themselves. If they fail to do so, the platforms are even given opportunities to make improvements. Only gradually - if the risks are not sufficiently minimized - does the sanctions regime take effect. It is then also possible to give platforms concrete specifications for the design and architecture of their platforms and to prescribe (interface) designs or (algorithm) architectures. The Digital Markets Act goes much further. As an ultima ratio, it provides for exclusion of a gatekeeper from the market.

Some commentators see the proposed regulatory regime as borrowing from financial market regulation. There, the listing of securities can be suspended if orderly trading is temporarily jeopardized or if this appears necessary to protect investors. These interventions in the free flow of market activity are known as 'circle breakers'. Such ad hoc interventions are not initially found in the repertoire of the Digital Services Act. Rather, incisive measures are only possible after a chain of misconduct. Like trading in financial products, the marketplace of opinions has become enormously automated and accelerated, especially on social networks. ${ }^{71}$ In extreme cases of virally spread hatred, disinformation, and other content dangerous to weighty legal assets, a kind of 'circle breaker' could be considered, so that in extreme situations 'trading' would also have to be suspended on social media. This measure, which fits into the canon of measures recommended by Vogl ("Increase frictions, reduce speed, insert cool-down periods, extend pauses, increase signal noise, disrupt circuits, interrupt automatisms, shut down."), remains the responsibility of individual users and civil society. ${ }^{72}$

70 Lorna Woods and Bernd Holznagel, "Rechtsgüterschutz im Internet - Regulierung durch Sorgfaltspflichten in England und Deutschland", Juristen Zeitung No. 6 (March 19, 2021).

71 Armin Nassehi. Muster, Munich, 2019.

72 James William, Stand out of our light: Freedom and resistance in the attention economy, New York 2018; Jenny Odell, How to do nothing: Resisting the Attention Econo- 


\section{Bibliography}

Aral, Sinan. The Hype Machine: How Social Media Disrupts Our Elections, Our Economy and Our Health - and how we must adapt. London, 2020.

Bayer, Judit. "Double harm to voters: data-driven micro-targeting and democratic public discourse.” Internet Policy Review, 9(1) (2020). https://doi.org/10.14763/ 2020.1.1460.

Bundeskartellamt. Case Summary, Facebook, Exploitative business terms pursuant to Section 19(1) GWB for inadequate data processing (February 15, 2019), https://www.bundeskartellamt.de/SharedDocs/Entscheidung/EN/Fallbericht e/Missbrauchsaufsicht/2019/B6-22-16.pdf?_blob=publicationFile\&v=4

Busch, Christoph. Regulating Digital Platforms as Infrastructure for Services of General Interest, 2021.

European Commission. Communication from the commission to the European Parliament, the Council, the European Economic and Social Committee and the Committee of the Regions, On the European democracy action plan. Brussels, 3.12.2020.

European Commission. Proposal for a Regulation of the European Parliament and of the Council on a Single Market For Digital Services (Digital Services Act) and amending Directive 2000/31/EC, 2021, Brussels, 15.12.2020.

European Commission. Proposal for a Regulation of the European Parliament and of the Council on contestable and fair markets in the digital sector (Digital Markets Act). Brussels, 15.12.2020.

Encke, Julia, Staun, Harald. "Die Nutzer spielen mit." Frankfurter Allgemeine Sonntagszeitung, March 14, 2021. https:/www.faz.net/aktuell/feuilleton/debatte $\mathrm{n}$ /plattformkapitalismus-joseph-vogl-ueber-kapital-und-ressentiment-17241098.h tml?printPagedArticle=true\#pageIndex_2.

Eyal, Nir. Hooked: How to build habit forming products. London 2019.

Fielitz, Maik, Marcks, Hoger. Digitaler Faschismus: Die sozialen Medien als Motor des Rechtsextremismus. Berlin, 2020.

Gerpott, Torsten. „Wer reguliert zukünftig Betreiber großer Online-Plattformen?" Wirtschaft und Wettbewerb, No. 9 (2021): 481-487.

Gorwa, Robert, Binns, Reuben, Katzenbach, Christian. Algorithmic content moderation: technical and political challenges in the automation of platform governance. Big Data \& Society, 2020.

Andreas Grünwald. "Big Tech-Regulierung zwischen GWB-Novelle und Digital Markets Act”, MMR - Zeitschrift für IT-Recht und Recht der Digitalisierung. No. 12 (2020): 822-826.

Helberger, Natali. On the Democratic Role of News Recommenders. Digital Journalism 2019, 993-1012. DOI: 10.1080/21670811.2019.1623700.

my, London, 2019; Geert Lovink, Sad by Design: On Platform Nihilism, London, 2019. 
Hwang, Tim. Subprime Attention Crisis. New York, 2020.

Kalbhenn, Jan and Hemmert-Halswick, Maximilian. „EU-weite Vorgaben für die Content-Moderation in sozialen Netzwerken. " ZUM - Zeitschrift für Urheber- und Medienrecht, No. 3 (2021): 185-194.

Kalbhenn, Jan „Designvorgaben für Chatbots, Deepfakes und Emotionserkennungssysteme: Der Vorschlag der Europäischen Kommission zu einer KI-VO als Erweiterung der medienrechtlichen Plattformregulierung“, ZUM - Zeitschrift für Urheber- und Medienrecht, No. 8/9 (2021) 663-674.

Klonick, Kate. The Facebook Oversight Board: Creating an Independent Institution to Adjudicate Online Free Expression. The Yale Law Journal, 2021

Kuang, Cliff, Fabricant, Robert. User Friendly - How the hidden rules of design are changing the way we live, work, and play. Penguin 2019.

Lovink, Geert. Sad by Design: On Platform Nihilism. London, 2019.

Scherling, Laura, DeRosa, Andrew, Ethics in Design and Communication. London, New York, 2020.

Nassehi, Armin. Muster: Theorie der digitalen Gesellschaft. Munich, 2019.

Odell, Jenny. How to do nothing: Resisting the Attention Economy: London, 2019.

Paal, Boris, Kumkar, Lea ,Die digitale Zukunft Europas‘,Zeitschrift für Digitalisierung und Recht, No 2 (2021): 97-131.

Staab, Philipp. Digitaler Kapitalismus: Markt und Herrschaft in der Ökonomie der Unknappheit. Berlin: Suhrkamp, 2019.

Srnicek, Nick. Platform Capitalsim. Cambridge 2017.

Vogl, Joseph. Kapial und Ressentiment. Berlin 2021.

William, James. Stand out of our light: Freedom and resistance in the attention economy: New York, 2018.

Woods, Lorna, Holznagel, Bernd 'Rechtsgüterschutz im Internet - Regulierung durch Sorgfaltspflichten in England und Deutschland' Juristen Zeitung No. 6 (March 19, 2021): 276-285.

Zuboff, Shoshana. The Age of Surveillance Capitalism: The Fight for a Human Future at the New Frontier of Power. New York: PublicAffairs, 2019.

\section{Annex: List of Europe's Digital Regulatory Instruments}

- e-Privacy Directive (Directive 2002/58/EC) - July $12^{\text {th }}, 2002$

- Aims at ensuring an equal level of protection of personal data processing, free movement of such data and of electronic commu- 
nication equipment and services in the community by setting out rules for providers of electronic communication services. ${ }^{73}$

- General Data Protection Regulation (GDPR; Regulation (EU) 2016/679) April 27 $7^{\text {th }}, 2016$

- Sets out rules regarding personal data processing according to the principle of graduated regulation to ensure the protection of fundamental rights, in particular their right to protection of personal data. ${ }^{74}$

- Code of Practice on Disinformation and related documents - October 2018

- Voluntary agreement signed by online platforms and advertisers as well as parts of the advertising industry that sets out self-regulatory standards to fight disinformation, monitor and improve online policies and ensure greater transparency and accountability. ${ }^{75}$

- Audiovisual Media Services Directive (AVMSD/ Directive 2018/1808) - Nov. 14th 2018

- Directive amending Directive 2010/13/EU extends media law regulation to video-on-demand and video-sharing platforms such as YouTube, Netflix or Facebook: Tighter protection of minors, ban on inflammatory, violent and terrorist content, quota for European productions. ${ }^{76}$

- Directive on Copyright in the Digital Single Market (Directive (EU) 2019/790) - April $17^{\text {th }} 2019$

- Includes new rules for fairer remuneration of creatives and rights holders, press publishers and journalists, especially when their works are used online, and increases transparency in their relationships with online platforms. ${ }^{77}$

- Platform to Business Regulation (P2B Regulation; Regulation (EU) 2019/1150) - June $20^{\text {th, }} 2019$

- Aims at increasing fairness and transparency to business users of online intermediation services and corporate websites in relation to online search engines by imposing transparency requirements on

73 https://eur-lex.europa.eu/legal-content/EN/ALL/?uri=CELEX\%3A32002L0058

74 https://eur-lex.europa.eu/legal-content/EN/TXT/?uri=CELEX\%3A02016R0679-201 60504\&qid=1532348683434

75 https://ec.europa.eu/info/strategy/priorities-2019-2024/new-push-european-democ racy/european-democracy-action-plan/strengthening-eu-code-practice-disinformati on_en

76 https://eur-lex.europa.eu/legal-content/EN/TXT/PDF/?uri=CELEX:32018L1808\&ri $\mathrm{d}=9$

77 https://eur-lex.europa.eu/eli/dir/2019/790/oj 
those providers that are established or reside in the EU and offer goods or services to consumers located in the EU. ${ }^{78}$

- Open Data Directive (Directive (EU) 2019/1024) - June 20 2019

- Aims at making public sector and publicly funded data re-usable and introducing the concept of high-value dataset and applies to content held by museums, libraries and archives (written texts, databases, audio files and film fragments); not: educational, scientific and Open Data Directive. ${ }^{79}$

- European strategy for data (COM/2020/66 final) - February $19^{\text {th }}, 2020$

- Aims at creating a single market for data allowing data sharing within the EU and across sectors benefiting businesses, researchers and public administrations. ${ }^{80}$

- Data-governance Act (COM/2020/767) - Nov. 25 th 2020

- Legislative proposal aiming at creating a framework that facilitates data-sharing and re-using of data laying down a voluntary registration framework for entities that collect and process data made available for altruistic purposes. ${ }^{81}$

- European Democracy Action Plan (COM/2020/790) - December $3^{\text {rd }}, 2020$

- Aims at promoting democratic participation in free and fair elections, strengthen media freedom/pluralism and counter disinformation, foreign interference and information influence operations through legislative and non-legislative measures. ${ }^{82}$

- Digital Services Act (DSA; COM/2020/825 final) - Dec. $15^{\text {th }}, 2020$

- Sets an accountability framework for online intermediary services/platforms to promote transparency, protect consumers and their online rights, and improve content moderation. Imposes different obligations for different categories of online intermediaries according to their role, size and impact online. ${ }^{83}$

- Amendment to the e-Commerce Directive adopted in 2000.

- Digital Markets Act (DMA; COM/2020/842 final)- Dec. 15 $5^{\text {th }}, 2020$

78 https://eur-lex.europa.eu/eli/dir/2019/790/oj

79 https://eur-lex.europa.eu/eli/dir/2019/1024/oj

80 https://ec.europa.eu/info/strategy/priorities-2019-2024/europe-fit-digital-age/europ ean-data-strategy_en

81 https://eur-lex.europa.eu/legal-content/EN/TXT/?uri=CELEX\%3A52020PC0767

82 https://ec.europa.eu/info/sites/default/files/edap_factsheet8.pdf

83 https://www.europarl.europa.eu/RegData/etudes/BRIE/2021/689357/EPRS_BRI(2 021)689357_EN.pdf 
- Sets criteria defining and prohibiting unfair practices by platforms that act as digital "gatekeepers" to the single market and provides market investigation-based enforcement mechanisms. ${ }^{84}$

- Artificial Intelligence Act (AI Regulation; COM/2021/206) - April 21 ${ }^{\text {st }}$, 2021

- Regulatory framework on the development, marketing and use of Artificial Intelligence that applies to providers of AI systems in the Union, users of AI systems located within the Union and providers and users of AI systems that are in a third country, where the output produced by the system is used in the Union..$^{85}$

84 https://ec.europa.eu/commission/presscorner/detail/en/ip_20_2347

85 https://eur-lex.europa.eu/legal-content/EN/TXT/?qid=1623335154975\&uri=CELE X\%3A52021PC0206 